\title{
Protective and Therapeutic Effects of Ghrelin in the Gut
}

\author{
Z. Warzecha* and A. Dembiński
}

\section{Department of Physiology, Jagiellonian University Medical College, Cracow, Poland}

\begin{abstract}
Ghrelin, a peptide predominantly produced in the stomach exhibits numerous physiological functions, including stimulation of growth hormone release, food intake and gastric empting, and regulation of energy expenditure. This peptide exhibits also some protective and healing-promoting effects. This review summarizes the recent findings concerning animal and human data showing protective and therapeutic effects of ghrelin in the gut.
\end{abstract}

Keywords: Colitis, food intake, gastric ulcer, ghrelin, healing, pancreatitis, protection.

\section{DISCOVERY OF GHRELIN}

Ghrelin has been primary isolated by Kojima et al. from the human and rat stomach [1], and the stomach is a main source of circulating ghrelin [2]. Ghrelin is an endogenous ligand for the growth hormone secretagogue receptor 1a (GHS-R) and acting on the anterior pituitary, ghrelin strongly and dose-dependently stimulates growth hormone release [1]. The sequence of events leading to the discovery of ghrelin was untypical. The discovery of this peptide has been preceded by the synthesis of its peptidyl and non-peptidyl analogs, called growth hormone secretagogues [3], and discovery [4], and cloning of GHS-R [5].

\section{GHRELIN AND ITS RECEPTORS}

Human ghrelin gene has been mapped to chromosome 3p26-25 [6]. Ghrelin is initially synthesized as preproghrelin composed of 117 amino acid residues, which are further processed to acyl ghrelin, des-acyl ghrelin and obestatin [7]. Circulating ghrelin exists mainly as a 28 amino acid peptide in two major forms, as acyl and des-acyl ghrelin [8]. Acyl ghrelin, which present in serum in far smaller quantities than des-acyl ghrelin, is recognized as an active form of this peptide because the acylation is necessary to the binding ghrelin with GHS-R1a. Ghrelin is the one and only peptide currently known to be octanoylated [1]. Before extracellular secretion, ghrelin undergoes posttraslatory estrification in which hydroxyl group of serine- 3 residue is acylated by n-octanoic acid (8-carbon fatty acid). In addition, there also some naturally occurring variants of acyl ghrelin. Hosoda et al. [9] have found that serine-3 residue apart from acylation by n-octanoic acid may be also decanoylated (C10:0), and possibly decenoylated (C10:1). DesGln14-ghrelin is another endogenous analog of ghrelin and this peptide is a result of alternative splicing of ghrelin gene undergoes the same process of acylation of serine- 3 residue and possesses the same hormonal activity as a 28 -residue ghrelin $[3 ; 10]$.

The enzyme that catalyzes the acylation of ghrelin has been discovered in 2008 and called ghrelin o-acyltransferase (GOAT) [11]. GOAT belongs to a family of hydrophobic membrane-bound acyltransferases and mRNA for GOAT is mainly restricted to the stomach, the major source of endogenous ghrelin [11]. Study in vitro has shown that the GOAT-containing membranes transfer the octanoyl group from octanoyl CoA to recombinant proghrelin, as well as to a pentapeptide containing only the N-terminal five amino acids of proghrelin [12]. Moreover, GOAT activity can be inhibited by an octanoylated ghrelin pentapeptide, suggesting that GOAT is subjected to end-product inhibition [12].

Des-acyl ghrelin does not bind to GHS-R1a and is deprived of growth hormone release activity. For this reason, des-acyl ghrelin was primary recognized as inactive form of ghrelin. However, several studies have shown that des-acyl ghrelin may exhibit some

*Address correspondence to this author at the Department of Physiology, Jagiellonian University Medical College, 16 Grzegórzecka str., 31-531 Cracow, Poland; Tel: +4812-4211006; Fax: +48-12-4225478; E-mail: mpwarzec@cyf-kr.edu.pl non-endocrinological actions including participation in the regulation of food intake, gut motility, adipogenesis, insulin secretion and resistance [13], as well as exerts cardiovascular [14; 15] and anti-proliferative effects [16]. These biological effects of des-acyl ghrelin are speculated to be a result of its binding to a novel, as yet unidentified receptor different from the classic ghrelin receptor, GHS-R1a [15].

Ghrelin is predominantly produced in the gastric oxyntic mucosa [1, 2, 17], but its presence was also detected in the most tissues, including among others the small and large bowel, pancreas, myocardium, pituitary or hypothalamus $[1,17,18]$. Total gastrectomy reduces serum level of ghrelin by $65 \%$ [2]. In the stomach, ghrelin is produced by the X/A-like cells. These cells represent about one fifth of all gastric endocrine cells in oxyntic mucosa [17]. X/A cells are small and round-shaped without contact with a stomach lumen (close-type cells). In the small and large bowel, there are two types of ghrelin-secreting cells. closed-type cells with triangular or elongated shapes, and opened-types cells with their apical cytoplasmic process contacting to the intestinal lumen [19]. The number of the opened-type cells gradually increases in the direction from the stomach to the lower gastrointestinal tract [20].

The presence of ghrelin-immunoreactive cells in the gut is agedependent. In the stomach, ghrelin-positive cells are present starting from $18^{\text {th }}$ day of the pregnancy and the number of these cells increases in an age-dependent manner from the neonatal to adult stage [21]. In contrast to that, in fetal period of life, pancreatic ghrelin cells are relatively numerous [22]. Later, the number of ghrelin-immunoreactive cells is reduced and these cells are localized at the periphery of human and rat pancreatic islets [22; 23].

Fasting plasma level of ghrelin is negatively correlated with body mass index in adult humans [24]. Obesity, food intake and glucose administration decrease plasma ghrelin concentration [2, $24,25]$; whereas fasting or anorexia nervosa increase plasma level of this peptide [2, 24].

The human GHS-R gene is located on human chromosome 3, at the position 26-27 and consists of two exons; the first exon encodes transmembrane domains 1-5, and the second exon encodes transmembrane domains 6 and 7 [26]. Two types of ghrelin receptor cDNAs have been identified, GHS-R cDNA $1 \mathrm{a}$ and, GHS-R cDNA 1b. GHS-R cDNA type 1a encodes functional receptor for ghrelin [26]. GHS-R1a is a typical G protein-coupled receptor (GPCR) with seven transmembrane domains and molecular mass of $41 \mathrm{kDa}$ [3]. Binding GHS or ghrelin to GHS-R1a activates phospholipase C to generate $\mathrm{IP}_{3}$ and diacylglycerol, leading to an increase in intracellular $\mathrm{Ca}^{2+}$. Activation of GHS-R1a also causes an inhibition of $\mathrm{K}^{+}$ion channels, leading to entry of $\mathrm{Ca}^{2+}$ through voltageoperating L-type channels [3]. GHS-R cDNA type $1 \mathrm{~b}$ is a result of alternative splicing mechanism [26]. It is derived from only the first exon and encodes only five of the seven predicted transmembrane domains. Although mRNA for GHS-R1b does not seem to end in the transcription of the protein, expression of this mRNA is 
widespread in many organs, but its significance remains to be determined $[3,18]$.

GHS-R1a mRNA is predominantly expressed in the pituitary and hypothalamus; however their presence has also been shown in other central and peripheral tissues, but at much lower levels [18, 26]. GHS-R expression is highly sensitive to a level of growth hormone. In growth hormone-deficient $d w / d w$ dwarf rats, expression of mRNA for GHS-R is increased, and administration of growth hormone reduced expression of this receptor in these rats [27]. Expression of GHS-R is also related to growth hormonereleasing hormone $(\mathrm{GH}-\mathrm{RH})$ and growth hormone secreatogogues (GHSs). Intravenous treatment with GH-RH increases expression of GHS-R mRNA in the pituitary and this effect is independent of somatostatin [28]. On the other hand, administration of GHSs down-regulates the GHS-R mRNA expression [28].

\section{MAIN BIOLOGICAL EFFECTS OF GHRELIN}

The main physiological function of ghrelin found by Kojima was strong and dose dependent stimulation of growth hormone release from the anterior pituitary [1]. This effect has been observed both in vivo and in vitro studies indicating direct action of ghrelin on somatotroph cells. However, the involvement of the hypothalamus in ghrelin-mediated release of growth hormone has been also found. GH-RH neurons express GHS-R [29] and systemic administration of GHS increases c-fos expression in GH-RHcontaining neurons [30]. Moreover, systemic treatment with GHS causes a $50 \%$ increase in GH-RH pulse frequency in portal blood of the pituitary [31]. In agreement with these findings is observation that release of growth hormone in patients with organic lesion in the hypothalamic area and treated with ghrelin is more than 35 -fold lower than in control group [32]. There are also data showing the involvement of vagal nerve in the ghrelin-induced secretion of growth hormone. Vagotomy, as well as blockade of the gastric vagal nerves by capsaicin abolish the ghrelin-induced GH secretion and activation of GH-RH-producing neurons [33]. Activity of ghrelin also includes stimulatory effect on the release of adrenocortocotropic hormone (ACTH), corticosterone and prolactin [34]

Beside a release of growth hormone, administration of ghrelin generates a positive energy balance. Peripheral or intracerebroventricular treatment with ghrelin increases food intake and fat deposition in rats [35]. Also human studies indicate that intravenous administration of ghrelin stimulates food intake from a free-choice buffet [36]. The orexigenic effect of ghrelin is mediated by activation of hypothalamic neurons expressing neuropeptide Y, agouti-related protein (AgRP) [37] and orexin [38], as well as by inhibition of hypothalamic proopiomelanocortin (POMC) neurons [39]. There are also papers showing that orexigenic effect of ghrelin involves the influence of this peptide on vagal nerve activity. Satiety peptides such as cholecystokinin, increase gastric vagal afferent discharge. In contrast to that ghrelin decreases activity of afferent vagal nerves [40]. Apart from an increase in appetite, the ghrelin-induced positive energy balance involves a decrease in energy expenditure and a reduction in cellular fat oxidation [41].

Ghrelin affects the development and maturation of digestive tract organs and this effect is age-dependent. In young suckling rats, administration of ghrelin reduces gastric and pancreatic growth; whereas in young adult rats, treatment with ghrelin stimulates gastric and pancreatic growth and increases pancreatic activity of amylase [42-44].

Ghrelin stimulates gastric motility [45] and gastric emptying [46]. Influence of ghrelin on gastric acid secretion is unclear. Some studies with anesthetized rats have shown that intravenous [45] or intracerebroventricular administration of ghrelin [47] stimulates gastric acid secretion. Another study with conscious rats has shown that central administration of ghrelin inhibits gastric acid secretion [48]; whereas a study performed in rats with chronic gastric fistulas or ligation of pylorus suggests that ghrelin does not affect secretion of acid in the stomach [46].

The role of ghrelin in endocrine and exocrine pancreatic secretion is likewise under debate. Some studies have reported that ghrelin inhibits insulin secretion in the isolated rat pancreas perfused in situ [49], in anesthetized mice and isolated mouse islets [50] and in humans [51]. In contrast to that, other studies have shown that ghrelin stimulates insulin secretion in isolated rat pancreatic islets [23] and in anesthetized rats [52]. These discrepancies may be a result of species differences and/or experimental conditions. Effect of ghrelin on pancreatic exocrine secretion seems to be more established. Experiments performed by Zhang et al. [53] have shown that intravenous administration of ghrelin inhibits the cholecystokinin- and 2-deoxy-D-glucosestimulated pancreatic exocrine secretion in anesthetized rats, as well as that ghrelin inhibits the potassium-stimulated amylase secretion from isolated pancreatic lobules. These observations are supported by data obtained by Kapica et al. [54]. They have studied the influence of pentaghrelin, an active fragment of ghrelin, on pancreatic juice secretion in anaesthetized rats. Intravenous administration of pentaghrelin has dose-dependently reduced the secretion of pancreatic juice and pancreatic protein output in basal conditions and after stimulation by cholecystokinin. Administration of pentaghrelin has failed to affect pancreatic secretion in rats subjected to vagotomy, capsaicin deactivation of afferent nerves or pretreatment with CCK1 receptor antagonist [54]. On the other hand, intracerebroventricular administration of ghrelin has been reported to increase pancreatic exocrine secretion via the vagal nerves in conscious rats [55].

Previous studies have shown that treatment with ghrelin protects the heart [56], kidney [57] and brain [58] against ischemic injury and attenuates sepsis-induced lung injury and mortality [59]. Animal studies have shown that administration of hexarelin, a synthetic GHS, as well as ghrelin reduces infarct size in isolated working rat hearts subjected to 30 minutes of ischemia followed by 120 minutes of reperfusion [56]. This effect has been partly abolished by the protein kinase $\mathrm{C}$ inhibitor [56]. These observations suggest that cardioprotective effect of GHS is independent of growth hormone secretion. This concept is additional supported by findings that GHSs exhibit cardioprotective effect in hypophysectomized rats [60] and ghrelin, and even des-acyl ghrelin inhibit apoptosis of cultured primary adult and $\mathrm{H} 9 \mathrm{c} 2$ cardiomyocytes [61]. Human studies have shown that chronic administration of ghrelin in patients with chronic heart failure leads to increase in left ventricular ejection fraction and ventricular mass, as well as to decrease in left ventricular end-systolic volume [62]. These effects have been associated with the ghrelin-induced increase in peak workload and peak oxygen consumption during exercise, muscle strength, and lean body mass. Moreover, long-lasting treatment with ghrelin has significantly decreased plasma concentration of norepinephrine in patients with chronic heart failure [62]. This last observation is in agreement with finding that administration of ghrelin decreases systolic and diastolic blood pressure in lean and overweight or obese subjects in resting conditions, as well as reduces the stress-induced increase in blood pressure, heart rate and muscle sympathetic nervous system activity in these groups of humans [63].

\section{PROTECTIVE EFFECTS OF GHRELIN IN THE GUT}

Protective effect of ghrelin administration has been found in different organs of the gut such as the stomach, pancreas, intestine and liver.

\section{Gastroprotective Effect of Ghrelin}

Pretreatment with ghrelin protects gastric mucosa against damage evoked by ethanol, stress, ischemia-reperfusion, 
alendronate or $\mathrm{HCl}$. In 2003, Sibilia et al. have reported that intracerebroventricular treatment with ghrelin causes dosedependent reduction in ethanol-induced gastric ulcers in conscious rats [64]. Protective effect of ghrelin given subcutaneously was much weaker, only ulcer depth has been significantly reduced. Moreover, they have found that inhibition of NO synthesis and capsaicin-induced sensory nerves denervation, but not vagotomy prevents the gastroprotective effect of ghrelin given centrally. For this reason Sibilia et al. have concluded that gastroprotective effect of ghrelin is mediated by endogenous NO release and requires the integrity of sensory nerve fibers [64]. In partial harmony with these findings are observation performed in rats by Konturek et al. [65]. They have found that peripheral intraperitoneal pretreatment with ghrelin reduces dose-dependently acute gastric lesions, improves gastric mucosal blood flow and reverses the ethanol-induced increase in gastric mucosal expression of tumor necrosis factor- $\alpha$. On the other hand, they have also observed that pretreatment with indomethacin, which has suppressed the mucosal generation of prostaglandin $\mathrm{E}_{2}$ by about $85 \%$, has augmented the ethanol-induced gastric lesions and eliminated the ghrelin-induced protection of mucosa against ethanol. Later, the role of prostaglandin $E_{2}$ in the ghrelin-induced gastroprotection against gastric injury evoked by ethanol has been also raised by other authors [66].

Pretreatment with ghrelin has been also found to protect gastric mucosa against injury evoked by water immersion and restraint stress (WRS) [67]. Intraperitoneal administration of exogenous ghrelin has been found to increase gastric acid secretion and attenuate gastric lesions induced by WRS. These effects were accompanied by a significant rise in plasma ghrelin level, gastric mucosal blood flow and luminal NO concentrations. The ghrelininduced protection has been attenuated by suppression of cyclooxygenases, deactivation of afferent nerves and inhibition of nitric oxide synthase (NOS) [67]. Brzozowski et al. has also found that protective effect of ghrelin given intraperitoneally is abolished by vagotomy [67]. This last effect is in contrast to results obtained by Sibilia at al. [64]. These discrepancies seem to be a result of different routes of ghrelin administration and models of mucosal injury. In study performed by Sibilia et al., ghrelin has been administered centrally and gastric ulcers have been induced by intragastric application of ethanol.

Ghrelin has been also found to protect rat gastric mucosa against damage evoked by ischemia followed by reperfusion. This effect has been observed after ghrelin given intraperitoneally [6870] and intracerebroventricularly [70]. Studies performed by Konturek et al. [68] have shown that administration of ghrelin significantly attenuates the ischemia/reperfusion-induced gastric lesions and this effects is associated with an increase in gastric mucosal blood flow, a decrease in plasma TNF- $\alpha$ and a reduction in NF- $\kappa B$ activation. As in other model of gastric ulcers, deactivation of sensory nerves with capsaicin [68-70], inhibition of cNOS by LNNA [68], inhibition of prostaglandin $\mathrm{E}_{2}$ production by blockade of cyclooxygenases [69] or vagotomy [70] has significantly attenuated the protective activity of ghrelin in ischemia/reperfusion-induced gastric ulcers [68]. Moreover, Brzozowski et al. [69] have shown that protective effect of ghrelin in this mode of gastric injury has been attenuated by pretreatment with d-Lys(3)-GHRP-6, a selective antagonist of GHS-R1a. In ischemia/reperfusion-induced gastric injury, protective effect of ghrelin seems to be also related to reduction in myeloperoxidase activity and mucosal content of malonyldialdehyde (MDA), a product of lipid peroxidation [69].

Sodium alendronate sodium, an amino bisphosphonate, is widely used in the treatment of various diseases that are associated with bone resorption, such as postmenopausal osteoporosis and Paget's disease. Işeri et al. [71] have shown that treatment with ghrelin attenuates gastric mucosa damage evoked by alendronate and this effect has been associated with a reduction in the alendronate-induced increase in serum TNF- $\alpha$ concentration, gastric
MDA content and myeloperoxidase activity. Moreover, treatment with ghrelin has been reported to reverse the alendronate-induced decrease in gastric mucosa glutathione concentration [71]. They have concluded that ghrelin reduces alendronate-induced gastric damage and this effect is related to ghrelin's anti-inflammatory and antioxidant properties. Interestingly, Işeri et al. have used ghrelin at the dose of $10 \mathrm{ng} / \mathrm{kg} / \mathrm{day}$. This dose is 1000 fold lower than doses used by other investigators [64-70, 72].

Gastroprotective effect of ghrelin has been also tested in gastric damage induced by intragastric administration of $0.6 \mathrm{~N} \mathrm{HCl}$. Adami et al. [72] have found that pretreatment of conscious rats with ghrelin administered intraperitoneally at the dose of $40 \mu \mathrm{g} / \mathrm{kg}$ significantly reduces by $43 \%$ gastric lesions evoked by concentrated $\mathrm{HCl}$. This effect has been abolished by prior intraperitoneal administration of GHS-R1a antagonist, [D-Lys ${ }^{3}$ ]GHRP-6 or by subcutaneous injection of histamine H3 receptor antagonist, UCL2138. Neither [D-Lys ${ }^{3}$ ]-GHRP-6 nor UCL2138 given without ghrelin has modified $\mathrm{HCl}$-induced gastric damage. This observation indicates that gastroprotective effect of ghrelin involves the release of histamine, which enhances gastric mucosal defense through the activation of histamine H3 receptors [72]. Moreover, this observation taken together with gastroprotective effects of ghrelin in other models of gastric injury suggest that ghrelin-induced protection of the stomach exhibits universal nature and is independent of type of noxious agent.

\section{Protective Effect of Ghrelin Administration in the Intestine}

Wu et al. [73] have investigated the influence of intravenous and intracerebroventricular ghrelin administration on the ischemia/reperfusion-induced intestinal injury. Rats were exposed to gut ischemia by clamping of mesenteric artery for $90 \mathrm{~min}$ followed by reperfusion for next $2 \mathrm{~h}$. Immediately after removing of microvascular clip ghrelin has been administered intravenously over a period of $30 \mathrm{~min}$. Intracerebroventricular administration of ghrelin has been performed at the beginning of reperfusion. Wu et $a l$. have found that intravenous ghrelin administration inhibits proinflammatory cytokine release, reduces neutrophil infiltration in the intestine and lungs, ameliorates intestinal barrier dysfunction, attenuates intestinal and pulmonary injury, and improves survival of rats after gut ischemia/reperfusion-induced injury. Similar protective effect has been observed after intracerebroventricular administration of ghrelin. Wu et al. have also observed that intravenous administration of GHS-R1a antagonist increases the ischemia/reperfusion-induced intestinal and pulmonary injury and animal mortality [73]. Beneficial effect of intravenous administration of ghrelin has been completely eliminated by previous vagotomy. Data obtained by $\mathrm{Wu}$ et al. indicate that administration of ghrelin is able to reduce intestinal and pulmonary injury and inflammation in gut ischemia followed by reperfusion.

\section{Protective Effect of Ghrelin Administration in the Pancreas}

Animal studies have shown that pretreatment with ghrelin inhibits the development of cerulein-, ischemia/reperfusion- and taurocholate-induced acute pancreatitis. In 2003 we have found that intraperitoneal treatment with ghrelin attenuates the development of acute pancreatitis evoked by cerulein [74]. Development of acute pancreatitis by cerulein leads to pancreatic damage associated with an increase in biochemical markers of acute pancreatitis severity. Plasma lipase activity and plasma concentration of proinflammatory interleukin- $1 \beta$ are increased; whereas pancreatic DNA synthesis, an index of pancreatic cell proliferation is decreased. We have observed that administration of ghrelin reduces pancreatic inflammatory infiltration and vacuolization of acinar cells, and reverses the cerulein-evoked increase in plasma activity of lipase and plasma concentration of interleukin-1 $\beta$, as well as increases pancreatic DNA synthesis. These findings have suggested 
that protective effect of ghrelin administration against ceruleininduced pancreatitis involves the inhibition of inflammatory process and the reduction in liberation of pro-inflammatory interleukin-1 $\beta$.

In 2006 we have shown that administration of ghrelin inhibits the development of ischemia/reperfusion-induced acute pancreatitis and using pituitary-intact and hypophysectomized rats, we have demonstrated the involvement of growth hormone $(\mathrm{GH})$ and insulin-like growth factor-1 (IGF-1) in this effect [75]. In pituitaryintact rats, treatment with ghrelin has attenuated the development of ischemia/reperfusion-induced pancreatitis and this effect was associated with partial reversion of the pancreatitis-evoked decrease in serum concentration of GH and IGF-1. Hypophysectomy has eliminated $\mathrm{GH}$ from the serum and reduced serum IGF-1 concentration by $90 \%$ and these effects were associated with an increased in the severity of ischemia/reperfusion-induced pancreatitis. Administration of ghrelin was without any beneficial effect in hypophysectomized rats. In contrast, administration of IGF-1 in hypophysectomized rats has reduced the severity of acute pancreatitis. These observations indicate that protective effect of ghrelin against the development of ischemia/reperfusion-induced pancreatitis is closely dependent on the release of GH and IGF-1.

Influence of treatment with ghrelin on the development of severe taurocholate-induced pancreatitis has been studied by Zhou and Xue [76, 77]. They have found that injection of sodium taurocholate into the pancreaticobiliary duct leads to the development of morphological signs of pancreatic and hepatic damage and this effect is associated with an increase in serum amylase activity and serum concentration of TNF- $\alpha$, interleukin- $1 \beta$, and interleukin-6. Moreover, they have observed that induction of acute pancreatitis by taurocholate increases pancreatic and hepatic expression of NF- $\mathrm{KB}$ p65 [76]. Treatment with ghrelin has been found to attenuate the morphological signs of damages in the pancreas and liver, and reduce the serum parameters of systemic inflammation, and the severity of acute pancreatitis. They have also shown that administration of ghrelin reduces pancreatic and hepatic expression of nuclear factor (NF) $\kappa \mathrm{B}$ p65. Zhou and Xue have concluded that ghrelin inhibits the development of acute pancreatitis induced by sodium taurocholate and this protective effect involves inhibition of NF- $\kappa B$ expression, leading to blockade of inflammatory signal transduction and reduction in the release of pro-inflammatory cytokines [76].

This finding has been supported and extended by next study performed by Zhou and Xue [77]. They have additionally found that exogenous ghrelin attenuates the severity of acute lung injury induced by the taurocholate-evoked acute pancreatitis. Mechanism of this protective effect of ghrelin seems to be the effect of reduction in neutrophil sequestration, limitation of proinflammatory cytokines release, and inhibition of pulmonary substance $\mathrm{P}$ expression.

In the pancreas, ghrelin has been also found to protect pancreatic $\beta$ cells. Granata et al. [78] have investigated the effect of acyl ghrelin and des-acyl ghrelin on cell survival of cultured HITT15 pancreatic $\beta$ cells. They have shown that both acyl and desacyl ghrelin equally prevents $\beta$ cell death induced by serum withdrawal. In addition, both peptides inhibit the serum starvationinduced apoptosis.

This observation has been extended by next study performed by Granata et al. [79]. They have demonstrated that acyl and des-acyl ghrelin promotes survival of both $\beta$ cells and human islets. These effects are independent of GHS-R1a, are likely mediated by acyl ghrelin/des-acyl ghrelin binding sites, and involve cAMP/PKA, ERK1/2, and PI3K/Akt [79].

Protective effect of ghrelin on $\beta$ pancreatic cell has been also reported by Wang et al. [80, 81]. Lipotoxicity plays an important role in underlying mechanism of type 2 diabetes. Prolonged exposure of pancreatic $\beta$ cells to elevated levels of fatty acid is associated with $\beta$ cell apoptosis. Studies performed by Wang et al. have shown that ghrelin promotes cell survival and attenuates the palmitate-induced apoptosis in pancreatic $\beta$ cell line MIN6. Exposure of MIN6 cells to ghrelin causes a rapid activation of protein kinase B (PKB) and inhibition of c-Jun N-terminal kinase (JNK) under lipotoxic state. Furthermore, LY294002, a phosphoinositide-3-kinase (PI3K) inhibitor, abolishes the antilipotoxic effect of ghrelin, as well as the ghrelin-induces inhibition of JNK, while JNK inhibitor, SP600125 enhances protective effect of ghrelin on MIN6 cells. Ghrelin also inhibits the mitochondrial pathway of apoptosis and it down-regulates Bax in MIN6 cells. In secretion experiment, ghrelin has suppressed insulin release under palmitate-incubated state. These findings suggest that ghrelin may prevent lipotoxicity-induced apoptosis in MIN6 cells through activation of $\mathrm{PKB}$, inhibition of JNK and mitochondrial pathway [80]. Wang et al. have also suggested that ghrelin protects pancreatic $\beta$ cells from lipotoxicity by inhibiting the nuclear translocation of the transcription regulator FoxO1 [81].

\section{Protective Effect of Ghrelin on the Liver}

Clinical studies have suggested that high fasting serum level of ghrelin prevents humans against development of gallstone disease [82] and nonalcoholic fatty liver disease [83]. Protective effect of ghrelin on the liver has been also shown in animal experimental studies. Treatment with ghrelin reduces the acetaminophen-induced liver injury [84] and the carbon tetrachloride-induced liver injury [85]. Cetin et al. have suggested that hepatoprotective effect of ghrelin is related to a reduction in oxidative stress [85]. Moreover, Arici et al. have shown that administration of exogenous ghrelin reduces the carbon tetrachloride-induced coagulation disturbances in rats [86].

\section{THERAPEUTIC EFFECTS OF GHRELIN IN THE GUT}

As shown above, pretreatment with ghrelin inhibits the development of damage or inflammation in the stomach, duodenum, intestine, pancreas and liver. However, protective effect requires administration of ghrelin before exposure to damaging factor and therefore has a limited clinical value. Clinically patients are usually seen several hours or days after the onset of the disease and therapy is usually started after admission to the hospital. For this reason, therapeutic effects of ghrelin in the gut are more important than protective effects of this peptide.

Our experimental studies performed on rats have shown that treatment with exogenous ghrelin accelerates healing of gastric and duodenal ulcers evoked by acetic acid [87]. Chronic ulcers were induced in pituitary-intact or hypophysectomized rats. After induction of ulcers, rats were treated intraperitoneally twice a day with saline, ghrelin or IGF-1 for six or ten days. In animals with intact pituitary, treatment with ghrelin increased serum level of GH and IGF-1. These effects were accompanied by the increase in mucosal cell proliferation, mucosal blood flow and healing rate of gastric and duodenal ulcers. After hypophysectomy, the significant increase in serum level of endogenous ghrelin was observed, but the healing of gastric and duodenal ulcers was delayed. This effect was accompanied by a significant decrease in serum concentration of endogenous GH and IGF-1, and reduction in mucosal blood flow and DNA synthesis. In hypophysectomized rats, administration of exogenous ghrelin was without any effect on serum level of GH and IGF-1, healing rate of gastroduodenal ulcers or mucosal cell proliferation. In contrast to this effect, administration of IGF-1 increased mucosal cell proliferation, healing rate of gastroduodenal ulcers and mucosal blood flow in hypophysectomized rats. These findings indicate that treatment with ghrelin accelerates healing of chronic gastric and duodenal ulcers and this effect is mediated by the release of endogenous GH and IGF-1. 
Experimental studies have also shown that treatment with ghrelin exhibits therapeutic effect in the course of cysteamineinduced duodenal ulcers [88]. We have found that treatment with ghrelin increases healing rate of duodenal ulcers and this effect is related, at least in part, to improvement of duodenal mucosal blood flow, the increase in mucosal cell proliferation and antioxidant defense, as well as to reduction in mucosal oxidative stress and inflammatory response [88].

Studies performed on rats have also shown that treatment with ghrelin after development of cerulein-induced acute pancreatitis reduces the severity of this disease and accelerates pancreatic recovery [89]. This effect seems to be related to the ghrelin-evoked improvement of pancreatic blood flow, reduction in systemic and local inflammation and stimulation of pancreatic cell proliferation [89]. Moreover studies with hypophysectomized rats have shown that therapeutic effect of ghrelin in the course of cerulein-induced pancreatitis is indirect and involves the release of endogenous GH and IGF-1 [90].

Influence of ghrelin administration on experimental and clinical colitis is controversial. Gonzalez-Rey et al. have studied therapeutic effect of ghrelin in mouse model of colitis [91]. They have found that treatment with ghrelin significantly ameliorates the severity of the trinitrobenzene sulfonic acid (TNBS)-induced colitis; abrogating body weight loss, diarrhea, and inflammation; and increasing mouse survival. This therapeutic effect has been associated with down-regulation of both inflammatory $\mathrm{T}$ helper cell 1 (Th1)-driven autoimmune response through the regulation of a wide spectrum of inflammatory mediators. Moreover, GonzalezRey et al. have found that this healing effect involves regulatory $\mathrm{T}$ cells secreting interleukin-10 and transforming growth factor- $\beta 1$. Administration of ghrelin has been also shown to attenuate the recurrence of colitis after repeated administration of TNBS. Finally, Gonzalez-Rey et al. have concluded that treatment with ghrelin exhibits anti-inflammatory activity leading to inhibition of large bowel inflammatory response and restoration of mucosal immune tolerance at multiple levels. Moreover, they have suggested that ghrelin administration represents a novel possible therapeutic approach for the treatment of Crohn's disease and other Th1mediated inflammatory diseases, such as rheumatoid arthritis and multiple sclerosis [91].

In harmony with these findings are clinical and animal study performed by Konturek et al. [92]. The aim of their study was: (a) to examine the expression of ghrelin and TNF-alpha mRNA in the inflamed colonic mucosa of patients with ulcerative colitis, (b) to determine the effect of treatment with exogenous ghrelin on the healing of TNBS-induced colitis in rats, and (c) to assess the effects of ghrelin treatment on mRNA expression for iNOS and protein expression for COX-2 and PPAR $\gamma$ in colonic mucosa in intact animals and animals with colitis. Clinical part of study has shown that patients with ulcerative colitis exhibit a significant upregulation of mRNA for ghrelin and TNF- $\alpha$ in colonic mucosa as compared to that observed in healthy controls. The ratio of expression of ghrelin has been found to be well correlated with the grade of colonic inflammation and expression of TNF- $\alpha$. Animal part of study has shown that intraperitonel treatment ghrelin significantly accelerates the healing of TNBS-induced colitis and this effect is accompanied by an increase in iNOS mRNA expression and synthesis of COX-2 in the colonic mucosa. On the other hand, treatment with ghrelin has been without effect on synthesis of PPAR $\gamma$ in rats with TNBSinduced colitis. These findings suggests that endogenous and exogenous ghrelin protects and accelerates the healing of inflamed colonic mucosa and these effects are mediated, at least in part by $\mathrm{NO}$ and prostaglandins [92].

Opposite effects of ghrelin on the course of colitis has been found by De Smet et al. [93]. They have induced colitis in wildtype (ghrelin+/+), ghrelin knockout (ghrelin-/-) and non-inbred
Swiss mice by adding 3\% dextran sodium sulphate (DSS) to drinking water for 5 days. After induction of colitis, non-inbred Swiss mice have been subsequently divided to two groups, treated intaperitoneally with saline or ghrelin. De Smet et al. have reported that the colitis-induced body weight loss, histological damage, myeloperoxidase activity and interleukin- $1 \beta$ level are attenuated in ghrelin(-/-) mice when compared with ghrelin(+/+) mice. Moreover, they found that 10 days treatment of non-inbred Swiss mice with exogenous ghrelin enhances the severity of colitis, promotes inflammatory and increases colonic level of proinflammatory interleukin-1 $\beta$. Authors have concluded that endogenous and exogenous ghrelin enhances the colonic manifestations of dextran sodium sulphate-induced colitis in mice [93].

Inconsistency between therapeutic effect of ghrelin in colitis observed by Gonzalez-Rey et al. [91] and Konturek et al. [92] and deleterious effect of ghrelin in the course of this disease reported by De Smet et al. [93] may be explained by differences in methods of colitis induction. Moreover, study performed by De Smet et al. exhibits some methodological inefficiency. It is most likely that severity of colitis depends on total dextran sodium sulphate (DSS) intake and intake of DSS per body mass unit. Authors have declared that there was no difference in total water/DSS intake between experimental groups. However initial body mass of animals have not been shown and for this reason intake of DDS per body mass unit is unknown.

Very interesting clinical study has been reported by Adachi et al. from Osaka [94]. Body weight loss and reduction in serum ghrelin level are commonly observed after total gastrectomy. A prospective randomized placebo-controlled phase II study has been performed to elucidate whether exogenous ghrelin administration prevents postoperative body weight loss by improving appetite and oral food intake in patients after total gastrectomy due to gastric cancer. Patients have been treated intravenously with synthetic human ghrelin. This treatment has significantly increased appetite and food intake, and lowered body weight loss. Adachi et al. have concluded that short-term treatment with synthetic human ghrelin safely and effectively reduces postoperative body weight loss and improves appetite and food intake in patients after total gastrectomy.

The same medical team has also performed a prospective randomized placebo-controlled phase II clinical study to evaluate whether administration of exogenous ghrelin can ameliorate the postoperative oral food intake and body weight in patient after esophagectomy due to esophageal cancer [95]. Authors have found that treatment with ghrelin in these patients increases food intake and attenuates weight loss.

Ghrelin stimulates food intake and gastric empting. Moreover, animal studies has shown that abdominal surgery induces a rapid and long-lasting decrease in plasma acyl ghrelin level associated with a decrease in gastric and plasma ghrelin-O-acyltransferase (GOAT) protein concentration [96]. For these reasons ghrelin can be used in the treatment of functional dyspepsia and postoperative ileus. For example, animal studies have shown that administration of ghrelin or its analogs improves postoperative [97, 98] and septic ileus [99]. These findings encouraged investigators to perform clinical studies. Akamizu et al. have shown that repeated administration of ghrelin stimulates appetite in patients with functional dyspepsia [100]. Synthetic analogs of ghrelin have been also found to be effective in the treatment of diabetic gastroparesis [101] and postoperative ileus after partial colectomy [102].

\section{CONLUSIONS}

Ghrelin, a growth hormone release stimulating peptide exhibits numerous effects in the gut suggesting its application in the clinic. 
Animal studies have shown that ghrelin protects against damage different organs in the gut, such as the stomach, pancreas, liver and intestine. Experimental studies have also indicated that treatment with ghrelin accelerates the recovery in the course of gastric ulcer, acute pancreatitis and colitis. Animal and clinical studies have shown that ghrelin may be useful in the treatment of dyspepsia, postoperative and the septic shock-induced ileus and during recovery after total gastrectomy or esophagectomy. Further studies are indispensable to check ghrelin dosing, adverse effects and route of administration in clinical practice.

\section{REFERENCES}

[1] Kojima, M.; Hosoda, H.; Date, Y.; Nakazato, M.; Matsuo, H; Kangawa, K. Ghrelin is a growth-hormone releasing acylated peptide from stomach. Nature, 1999, 402, 656-660.

[2] Ariyasu, H. Takaya, K. Tagami, T; Ogawa, Y; Hosoda, K; Akamizu, T.; Suda, M.; Koh, T.; Natsui, K.; Toyooka, S.; Shirakami, G.; Usui, T.; Shimatsu, A.; Doi, K.; Hosoda, H.; Kojima, M.; Kangawa, K.; Nakao, K. Stomach is a major source of circulating ghrelin, and feeding state determines plasma ghrelin-like immunoreactivity levels in humans. J. Clin. Endocrinol. Metab., 2001, 86, 4753-4758.

[3] van der Lely, A.J.; Tschöp, M.; Heiman, M.L.; Ghigo, E. Biological, physiological, pathophysiological, and pharmacological aspects of ghrelin. Endocr. Rev., 2004, 25, 426-457.

[4] Pong, S.S.; Chaung, L.Y.; Dean, D.C.; Nargund, R.P.; Patchett, A.A.; Smith, R.G. Identification of a new G-protein-linked receptor for growth hormone secretagogues. Mol. Endocrinol., 1996, 10, 57-61.

[5] Howard, A.D.; Feighner, S.D.; Cully, D.F.; Arena, J.P.; Liberator, P.A.; Rosenblum, C.I.; Hamelin, M.; Hreniuk, D.L.; Palyha, O.C.; Anderson, J.; Paress, P.S.; Diaz, C.; Chou, M.; Liu, K.K.; McKee, K.K.; Pong, S.S.; Chaung, L.Y.; Elbrecht, A.; Dashkevicz, M.; Heavens, R.; Rigby, M.; Sirinathsinghji, D.J.; Dean, D.C.; Melillo, D.G.; Patchett, A.A.; Nargund, R.; Griffin, P.R.; DeMartino, J.A.; Gupta, S.K.; Schaeffer, J.M.; Smith, R.G.; Van der Ploeg, L.H. A receptor in pituitary and hypothalamus that functions in growth hormone release. Science, 1996, 273(5277), 974-977.

[6] Wajnraich, M.P.; Ten, I.S.; Gertner, J.M.; Leibel, R.L. Genomic organization of the human ghrelin gene. J. Endocr. Genet., 2000, 1, 231-233.

[7] Asakawa, A.; Ataka, K.; Fujino, K.; Chen, C.Y.; Kato, I.; Fujimiya, M.; Inui, A. Ghrelin family of peptides and gut motility. J. Gastroenterol. Hepatol., 2011, 26(Suppl 3), 73-74

[8] Silvia, W.D.; Kumar, B. Saga of ghrelin: its structure, action and therapeutic uses. Asian Biomed., 2010, 4, 855-860.

[9] Hosoda, H.; Kojima, M.; Mizushima, T.; Shimizu, S.; Kangawa, K. Structural divergence of human ghrelin. Identification of multiple ghrelinderived molecules produced by post-translational processing._J. Biol. Chem., 2003, 278, 64-70.

[10] Hosoda, H., Kojima, M. Matsuo, H.; Kangawa, K. Purification and characterization of rat des-Gln14-Ghrelin, a second endogenous ligand for the growth hormone secretagogue receptor. J. Biol. Chem., 2000, 275, 21995-2000.

[11] Yang, J.; Brown, M.S.; Liang, G.; Grishin, N.V.; Goldstein, J.L. Identification of the acyltransferase that octanoylates ghrelin, an appetitestimulating peptide hormone. Cell, 2008, 132, 387-396.

[12] Yang, J.; Zhao, T.J.; Goldstein, J.L.; Brown, M.S. Inhibition of ghrelin Oacyltransferase (GOAT) by octanoylated pentapeptides. Proc. Natl. Acad. Sci. U S A., 2008, 105, 10750-10755.

[13] Chen, C.Y.; Asakawa, A.; Fujimiya, M.; Lee, S.D.; Inui, A. Ghrelin gene products and the regulation of food intake and gut motility. Pharmacol. Rev., 2009, 61, 430-481.

[14] Li, L.; Zhang, L.K.; Pang, Y.Z.; Pan, C.S.; Qi, Y.F.; Chen, L.; Wang, X.; Tang, C.S.; Zhang, J. Cardioprotective effects of ghrelin and des-octanoyl ghrelin on myocardial injury induced by isoproterenol in rats. Acta Pharmacol. Sin., 2006, 27, 527-535.

[15] Lear, P.V.; Iglesias, M.J.; Feijóo-Bandín, S.; Rodríguez-Penas, D.; Mosquera-Leal, A.; García-Rúa, V.; Gualillo, O.; Ghè, C.; Arnoletti, E.; Muccioli, G.; Diéguez, C.; González-Juanatey, J.R.; Lago, F. Des-acyl ghrelin has specific binding sites and different metabolic effects from ghrelin in cardiomyocytes. Endocrinology, 2010, 151, 3286-3298.

[16] Cassoni, P.; Allia, E.; Marrocco, T.; Ghè, C.; Ghigo, E.; Muccioli, G.; Papotti, M. Ghrelin and cortistatin in lung cancer: expression of peptides and related receptors in human primary tumors and in vitro effect on the H345 small cell carcinoma cell line. J. Endocrinol. Invest., 2006, 29, 781-790.

[17] Date, Y.; Kojima, M.; Hosoda, H.; Sawaguchi, A.; Mondal, M.S.; Suganuma, T.; Matsukura, S.; Kangawa, K.; Nakazato, M. Ghrelin, a novel growth hormone-releasing acylated peptide, is synthesized in a distinct endocrine cell type in the gastrointestinal tracts of rats and humans. Endocrinology, 2000, $141,4255-4261$

[18] Gnanapavan, S.; Kola, B.; Bustin, S.A.; Morris, D.G.; McGee, P.; Fairclough, P.; Bhattacharya, S.; Carpenter, R.; Grossman, A.B.; Korbonits, M. The tissue distribution of the mRNA of ghrelin and subtypes of its receptor, GHS-R, in humans. J. Clin. Endocrinol. Metab., 2002, 87, 2988 2991.

[19] Sakata, I.; Sakai, T. Ghrelin cells in the gastrointestinal tract. Int. J. Pept., 2010, 2010. pii: 945056.

[20] Sakata, I.; Nakamura, K.; Yamazaki, M.; Matsubara, M.; Hayashi, Y.; Kangawa, K.; Sakai, T. Ghrelin-producing cells exist as two types of cells, closed- and opened-type cells, in the rat gastrointestinal tract. Peptides, 2002, 23, 531-536.

[21] Hayashida, T.; Nakahara, K.; Mondal, M.S.; Date, Y.; Nakazato, M.; Kojima, M.; Kangawa, K.; Murakami, N. Ghrelin in neonatal rats: distribution in stomach and its possible role. J. Endocrinol., 2002, 173, 239245.

[22] Wierup, N.; Svensson, H.; Mulder, H.; Sundler, F. The ghrelin cell: a novel developmentally regulated islet cell in the human pancreas. Regul. Pept., 2002, 107, 63-69.

[23] Date, Y.; Nakazato, M.; Hashiguchi, S.; Dezaki, K.; Mondal, M.S.; Hosoda, H.; Kojima, M.; Kangawa, K.; Arima, T.; Matsuo, H.; Yada, T.; Matsukura, $\mathrm{S}$. Ghrelin is present in pancreatic alpha-cells of humans and rats and stimulates insulin secretion. Diabetes, 2002, 51, 124-129.

[24] Shiiya, T.; Nakazato, M.; Mizuta, M.; Date, Y.; Mondal, M.S.; Tanaka, M.; Nozoe, S.; Hosoda, H.; Kangawa, K.; Matsukura, S. Plasma ghrelin levels in lean and obese humans and the effect of glucose on ghrelin secretion. J. Clin. Endocrinol. Metab., 2002, 87, 240-244.

[25] Tschöp, M.; Weyer, C.; Tataranni, P.A.; Devanarayan, V.; Ravussin, E. Heiman, M.L. Circulating ghrelin levels are decreased in human obesity. Diabetes, 2001, 50, 707-709.

[26] Kojima, M.; Kangawa, K. Ghrelin: structure and function. Physiol. Rev., 2005, 85, 495-522.

[27] Bennett, P.A.; Thomas, G.B.; Howard, A.D.; Feighner, S.D.; van der Ploeg, L.H.; Smith, R.G.; Robinson, I.C. Hypothalamic growth hormone secretagogue-receptor (GHS-R) expression is regulated by growth hormone in the rat. Endocrinology, 1997, 138, 4552-4557.

[28] Kineman, R.D.; Kamegai, J.; Frohman, L.A. Growth hormone (GH)releasing hormone (GHRH) and the GH secretagogue (GHS), L692,585, differentially modulate rat pituitary GHS receptor and GHRH receptor messenger ribonucleic acid levels. Endocrinology, 1999, 140, 3581-3586.

[29] Tannenbaum, G.S.; Lapointe, M.; Beaudet, A.; Howard, A.D. Expression of growth hormone secretagogue-receptors by growth hormone-releasing hormone neurons in the mediobasal hypothalamus. Endocrinology, 1998, $139,4420-4423$

[30] Kamegai, J.; Hasegawa, O.; Minami, S.; Sugihara, H.; Wakabayashi, I. The growth hormone-releasing peptide KP-102 induces c-fos expression in the arcuate nucleus. Brain Res. Mol. Brain Res., 1996, 39, 153-159.

[31] Fletcher, T.P.; Thomas, G.B.; Clarke, I.J. Growth hormone-releasing hormone and somatostatin concentrations in the hypophysial portal blood of conscious sheep during the infusion of growth hormone-releasing peptide-6. Domest. Anim. Endocrinol., 1996, 13, 251-258.

[32] Popovic,V.; Miljic, D.; Micic, D.; Damjanovic, S.; Arvat, E.; Ghigo, E.; Dieguez, C.; Casanueva, F.F. Ghrelin main action on the regulation of growth hormone release is exerted at hypothalamic level. J. Clin. Endocrinol. Metab., 2003, 88, 3450-3453.

[33] Date, Y.; Murakami, N.; Toshinai, K.; Matsukura, S.; Niijima, A.; Matsuo, H.; Kangawa, K.; Nakazato, M. The role of the gastric afferent vagal nerve in ghrelin-induced feeding and growth hormone secretion in rats. Gastroenterology, 2002, 123, 1120-1128.

[34] Arvat, E.; Maccario, M.; Di Vito, L.; Broglio, F.; Benso, A.; Gottero, C.; Papotti, M.; Muccioli, G.; Dieguez, C.; Casanueva, F.F.; Deghenghi, R.; Camanni, F.; Ghigo, E. Endocrine activities of ghrelin, a natural growth hormone secretagogue (GHS), in humans: comparison and interactions with hexarelin, a nonnatural peptidyl GHS, and GH-releasing hormone. J. Clin. Endocrinol. Metab., 2001, 86, 1169-1174.

[35] Wren, A.M.; Small, C.J.; Abbott, C.R.; Dhillo, W.S.; Seal, L.J.; Cohen, M.A.; Batterham, R.L.; Taheri, S.; Stanley, S.A.; Ghatei, M.A.; Bloom, S.R. Ghrelin causes hyperphagia and obesity in rats. Diabetes, 2001, 50, 25402547.

[36] Wren, A.M.; Seal, L.J.; Cohen, M.A.; Brynes, A.E.; Frost, G.S.; Murphy, K.G.; Dhillo, W.S.; Ghatei, M.A.; Bloom, S.R. Ghrelin enhances appetite and increases food intake in humans. J. Clin. Endocrinol. Metab., 2001, 86, $5992-5995$.

[37] Kamegai, J.; Tamura, H.; Shimizu, T.; Ishii, S.; Sugihara, H.; Wakabayashi, I. Chronic central infusion of ghrelin increases hypothalamic neuropeptide Y and agouti-related protein mRNA levels and body weight in rats. Diabetes, 2001, 50, 2438-2443.

[38] Toshinai, K.; Date, Y.; Murakami, N.; Shimada, M.; Mondal, M.S.; Shimbara, T.; Guan, J.L.; Wang, Q.P.; Funahashi, H.; Sakurai, T.; Shioda, S.; Matsukura, S.; Kangawa, K,; Nakazato, M. Ghrelin-induced food intake is mediated via the orexin pathway. Endocrinology, 2003, 144, 1506-1512.

[39] Riediger, T.; Traebert, M.; Schmid, H.A.; Scheel, C.; Lutz, T.A.; Scharrer, E. Site-specific effects of ghrelin on the neuronal activity in the hypothalamic arcuate nucleus. Neurosci. Lett., 2003, 341, 151-155.

[40] Asakawa, A.; Inui, A.; Kaga, T.; Yuzuriha, H.; Nagata, T.; Ueno, N.; Makino, S.; Fujimiya, M.; Niijima, A.; Fujino, M.A.; Kasuga, M. Ghrelin is an appetite-stimulatory signal from stomach with structural resemblance to motilin. Gastroenterology, 2001, 120, 337-345. 
[41] Currie, P.J.; Coiro, C.D.; Duenas, R.; Guss, J.L.; Mirza, A.; Tal, N. Urocortin I inhibits the effects of ghrelin and neuropeptide $\mathrm{Y}$ on feeding and energy substrate utilization. Brain Res., 2011, 1385, 127-134.

[42] Warzecha, Z.; Dembiński, A.; Ceranowicz, P.; Dembiński, M.; Cieszkowski, J.; Bielański, W.; Pawlik, W.W.; Kuwahara, A.; Kato, I. Dual age-dependent effect of ghrelin administration on serum level of insulin-like growth factor-1 and gastric growth in young rats. Eur. J. Pharmacol., 2006, 529, 145-150.

[43] Dembiński, A.; Warzecha, Z.; Ceranowicz, P.; Bielański, W.; Cieszkowski, J.; Dembiński, M.; Pawlik, W.W.; Kuwahara, A.; Kato, I.; Konturek, P.C. Variable effect of ghrelin administration on pancreatic development in young rats. Role of insulin-like growth factor-1. J. Physiol. Pharmacol., 2005, 56, 555-570.

[44] Warzecha, Z.; Dembiński, A.; Ceranowicz, P.; Dembiński, M.; Cieszkowski, J.; Konturek, S.J.; Polus, A.; Pawlik, W.W.; Kuwahara, A.; Kato, I.; Konturek, P.C. Influence of ghrelin on gastric and duodenal growth and expression of digestive enzymes in young mature rats. J. Physiol. Pharmacol., 2006, 57, 425-437.

[45] Masuda, Y.; Tanaka, T.; Inomata, N.; Ohnuma, N.; Tanaka, S.; Itoh, Z.; Hosoda, H.; Kojima, M.; Kangawa, K. Ghrelin stimulates gastric acid secretion and motility in rats. Biochem. Biophys. Res. Commun., 2000, 276, 905-908.

[46] Dornonville De La Cour, C.; Lindstrom, E.; Norlen, P.; Hakanson, R. Ghrelin stimulates gastric emptying but is without effect on acid secretion and gastric endocrine cells. Regul. Pept., 2004, 120, 23-32.

[47] Date, Y.; Nakazato, M.; Murakami, N.; Kojima, M.; Kangawa, K.; Matsukura, S. Ghrelin acts in the central nervous system to stimulate gastric acid secretion. Biochem. Biophys. Res. Commun., 2001, 280, 904-907.

[48] Sibilia, V.; Pagani, F.; Guidobono, F.; Locatelli, V.; Torsello, A.; Deghenghi, R.; Netti, C. Evidence for a central inhibitory role of growth hormone secretagogues and ghrelin on gastric acid secretion in conscious rats. Neuroendocrinology, 2002, 75, 92-97.

[49] Egido, E.M.; Rodriguez-Gallardo, J.; Silvestre, R.A.; Marco, J. Inhibitory effect of ghrelin on insulin and pancreatic somatostatin secretion. Eur. J. Endocrinol., 2002, 146, 241-244.

[50] Reimer, M.K.; Pacini, G.; Ahrén, B. Dose-dependent inhibition by ghrelin of insulin secretion in the mouse. Endocrinology, 2003, 144, 916-921.

[51] Broglio, F.; Benso, A.; Castiglioni, C.; Gottero, C.; Prodam, F.; Destefanis, S.; Gauna, C.; van der Lely, A.J.; Deghenghi, R.; Bo, M.; Arvat, E.; Ghigo, E. The endocrine response to ghrelin as a function of gender in humans in young and elderly subjects. J. Clin. Endocrinol. Metab., 2003, 88, 15371542 .

[52] Lee, H.M.; Wang, G.; Englander, E.W.; Kojima, M.; Greeley, G.H. Jr. Ghrelin, a new gastrointestinal endocrine peptide that stimulates insulin secretion: enteric distribution, ontogeny, influence of endocrine, and dietary manipulations. Endocrinology, 2002, 143, 185-190.

[53] Zhang, W.; Chen, M.; Chen, X.; Segura, B.J.; Mulholland, M.W. Inhibition of pancreatic protein secretion by ghrelin in the rat. J. Physiol., 2001, 537(Pt 1), 231-236.

[54] Kapica, M.; Laubitz, D.; Puzio, I.; Jankowska, A.; Zabielski, R. The ghrelin pentapeptide inhibits the secretion of pancreatic juice in rats. J. Physiol. Pharmacol., 2006, 57, 691-700.

[55] Sato, N.; Kanai, S.; Takano, S.; Kurosawa, M.; Funakoshi, A.; Miyasaka, K. Central administration of ghrelin stimulates pancreatic exocrine secretion via the vagus in conscious rats. Jpn. J. Physiol., 2003, 53, 443-449.

[56] Frascarelli, S.; Ghelerdoni, S.; Ronca-Testoni, S.; Zucchi, R. Effect of ghrelin and synthetic growth hormone secretagogues in normal and ischemic rat heart. Basic Res. Cardiol., 2003; 98, 401-405.

[57] Takeda, R.; Nishimatsu, H.; Suzuki, E.; Satonaka, H.; Nagata, D.; Oba, S.; Sata, M.; Takahashi, M.; Yamamoto, Y.; Terauchi, Y.; Kadowaki, T.; Kangawa, K.; Kitamura, T.; Nagai, R.; Hirata, Y. Ghrelin improves renal function in mice with ischemic acute renal failure. J. Am. Soc. Nephrol., 2006, 17, 113-121.

[58] Liu, Y.; Wang, P.S.; Xie, D.; Liu, K.; Chen, L. Ghrelin reduces injury of hippocampal neurons in a rat model of cerebral ischemia/reperfusion. Chin. J. Physiol., 2006, 49, 244-250.

[59] Wu, R.; Dong, W.; Zhou, M.; Zhang, F.; Marini, C.P.; Ravikumar, T.S.; Wang, P. Ghrelin attenuates sepsis-induced acute lung injury and mortality in rats. Am. J. Respir. Crit. Care Med., 2007, 176, 805-813.

[60] Locatelli, V.; Rossoni, G.; Schweiger, F.; Torsello, A.; De Gennaro Colonna, V.; Bernareggi, M.; Deghenghi, R.; Müller, E.E.; Berti, F. Growth hormoneindependent cardioprotective effects of hexarelin in the rat. Endocrinology, 1999, 140, 4024-4031.

[61] Baldanzi, G.; Filigheddu, N.; Cutrupi, S.; Catapano, F.; Bonissoni, S.; Fubini, A.; Malan, D.; Baj, G.; Granata, R.; Broglio, F.; Papotti, M.; Surico, N.; Bussolino, F.; Isgaard, J.; Deghenghi, R.; Sinigaglia, F.; Prat, M.; Muccioli, G.; Ghigo, E.; Graziani, A. Ghrelin and des-acyl ghrelin inhibit cell death in cardiomyocytes and endothelial cells through ERK1/2 and PI 3kinase/AKT. J. Cell Biol., 2002, 159, 1029-1037.

[62] Nagaya, N.; Moriya, J.; Yasumura, Y.; Uematsu, M.; Ono, F.; Shimizu, W.; Ueno, K.; Kitakaze, M.; Miyatake, K.; Kangawa, K. Effects of ghrelin administration on left ventricular function, exercise capacity, and muscle wasting in patients with chronic heart failure. Circulation, 2004, 110, 36743679 .

[63] Lambert, E.; Lambert, G.; Ika-Sari, C.; Dawood, T.; Lee, K.; Chopra, R.; Straznicky, N.; Eikelis, N.; Drew, S.; Tilbrook, A.; Dixon, J.; Esler, M.;
Schlaich, M.P. Ghrelin modulates sympathetic nervous system activity and stress response in lean and overweight men. Hypertension, 2011, 58, 43-50.

[64] Sibilia, V.; Rindi, G.; Pagani, F.; Rapetti, D.; Locatelli, V.; Torsello, A.; Campanini, N.; Deghenghi, R.; Netti, C. Ghrelin protects against ethanolinduced gastric ulcers in rats: studies on the mechanisms of action. Endocrinology, 2003, 144, 353-359.

[65] Konturek, P.C.; Brzozowski, T.; Pajdo, R.; Nikiforuk, A.; Kwiecien, S. Harsch, I.; Drozdowicz, D.; Hahn, E.G.; Konturek, S.J. Ghrelin-a new gastroprotective factor in gastric mucosa. J. Physiol. Pharmacol., 2004, 55, 325-336.

[66] Sibilia, V.; Pagani, F.; Rindi, G.; Lattuada, N.; Rapetti, D.; De Luca, V.; Campanini, N.; Bulgarelli, I.; Locatelli, V.; Guidobono, F.; Netti, C._Central ghrelin gastroprotection involves nitric oxide/prostaglandin cross-talk. $\mathrm{Br}$. J. Pharmacol., 2008, 154, 688-697.

[67] Brzozowski, T.; Konturek, P.C.; Konturek, S.J.; Kwiecień, S.; Drozdowicz, D.; Bielanski, W.; Pajdo, R.; Ptak, A.; Nikiforuk, A.; Pawlik, W.W.; Hahn, E.G. Exogenous and endogenous ghrelin in gastroprotection against stressinduced gastric damage. Regul. Pept., 2004, 120, 39-51.

[68] Konturek, P.C.; Brzozowski, T.; Walter, B.; Burnat, G.; Hess, T.; Hahn, E.G.; Konturek, S.J. Ghrelin-induced gastroprotection against ischemiareperfusion injury involves an activation of sensory afferent nerves and hyperemia mediated by nitric oxide. Eur. J. Pharmacol., 2006, 536, 171-81.

[69] Brzozowski, T.; Konturek, P.C.; Sliwowski, Z.; Pajdo, R.; Drozdowicz, D.; Kwiecien, S.; Burnat, G.; Konturek, S.; Pawlik, W.W. Prostaglandin/cyclooxygenase pathway in ghrelin-induced gastroprotection against ischemia-reperfusion injury. J. Pharmacol. Exp. Ther., 2006, 319, 477-487.

[70] Brzozowski, T.; Konturek, P.C.; Sliwowski, Z.; Drozdowicz, D.; Kwiecien, S.; Pawlik, M.; Pajdo, R.; Konturek, S.J.; Pawlik, W.W.; Hahn, E.G. Neural aspects of ghrelin-induced gastroprotection against mucosal injury induced by noxious agents. J. Physiol. Pharmacol., 2006, 57(Suppl. 6), 63-76.

[71] Işeri, S.O.; Sener, G.; Yüksel, M.; Contuk, G.; Cetinel, S.; Gedik, N.; Yegen, B.C. Ghrelin against alendronate-induced gastric damage in rats. $J$. Endocrinol., 2005, 187, 399-406.

[72] Adami, M.; Pozzoli, C.; Leurs, R.; Stark, H.; Coruzzi, G. Histamine H(3) receptors are involved in the protective effect of ghrelin against $\mathrm{HCl}$-induced gastric damage in rats. Pharmacology, 2010, 86, 259-266.

[73] Wu, R.; Dong, W.; Ji, Y.; Zhou, M.; Marini, C.P.; Ravikumar, T.S.; Wang, P. Orexigenic hormone ghrelin attenuates local and remote organ injury after intestinal ischemia-reperfusion. PLoS One, 2008, 3, e2026.

[74] Dembinski, A.; Warzecha, Z.; Ceranowicz, P.; Tomaszewska, R.; Stachura, J.; Konturek, S.J.; Konturek, P.C. Ghrelin attenuates the development of acute pancreatitis in rat. J. Physiol. Pharmacol., 2003, 54, 561-573.

[75] Dembiński, A.; Warzecha, Z.; Ceranowicz, P.; Cieszkowski, J.; Pawlik, W.W.; Tomaszewska, R.; Kuśnierz-Cabala, B.; Naskalski, J.W.; Kuwahara, A.; Kato, I. Role of growth hormone and insulin-like growth factor-1 in the protective effect of ghrelin in ischemia/reperfusion-induced acute pancreatitis. Growth Horm. IGF Res., 2006, 16, 348-356.

[76] Zhou, X.; Xue, C. Ghrelin inhibits the development of acute pancreatitis and nuclear factor kappaB activation in pancreas and liver. Pancreas, 2009, 38, $752-757$.

[77] Zhou, X.; Xue, C. Ghrelin attenuates acute pancreatitis-induced lung injury and inhibits substance P expression. Am. J. Med. Sci., 2010, 339, 49-54.

[78] Granata, R.; Settanni, F.; Trovato, L.; Destefanis, S.; Gallo, D.; Martinetti, M.; Ghigo, E.; Muccioli, G. Unacylated as well as acylated ghrelin promotes cell survival and inhibit apoptosis in HIT-T15 pancreatic beta-cells. $J$. Endocrinol. Invest., 2006, 29, RC19-RC22.

[79] Granata, R.; Settanni, F.; Biancone, L.; Trovato, L.; Nano, R.; Bertuzzi, F.; Destefanis, S.; Annunziata, M.; Martinetti, M.; Catapano, F.; Ghè, C.; Isgaard, J.; Papotti, M.; Ghigo, E.; Muccioli, G. Acylated and unacylated ghrelin promote proliferation and inhibit apoptosis of pancreatic beta-cells and human islets: involvement of 3',5'-cyclic adenosine monophosphate/protein kinase A, extracellular signal-regulated kinase 1/2, and phosphatidyl inositol 3-Kinase/Akt signaling. Endocrinology, 2007, 148, 512-529.

[80] Wang, W.; Zhang, D.; Zhao, H.; Chen, Y.; Liu, Y.; Cao, C.; Han, L.; Liu, G Ghrelin inhibits cell apoptosis induced by lipotoxicity in pancreatic beta-cell line. Regul. Pept., 2010, 161, 43-50.

[81] Wang, W.; Liu, Y; Chen, Y; Cao, C.; Xiang, Y; Zhang, D; Han, L.; Zhao, H.; Liu, G. Inhibition of Foxol mediates protective effects of ghrelin against lipotoxicity in MIN6 pancreatic beta-cells. Peptides, 2010, 31, 307-314.

[82] Mendez-Sanchez, N.; Ponciano-Rodriguez, G.; Bermejo-Martinez, L.; Villa, A.R.; Chavez-Tapia, N.C.; Zamora-Valdes, D., Pichardo-Bahena, R., Barredo-Prieto, B.; Uribe-Ramos, M.H.; Ramos, M.H.; Baptista-Gonzalez, H.A.; Uribe, M. Low serum levels of ghrelin are associated with gallstone disease. World J. Gastroenterol., 2006, 12, 3096-3100.

[83] Gutierrez-Grobe, Y.; Villalobos-Blasquez, I.; Sánchez-Lara, K.; Villa, A.R. Ponciano-Rodríguez, G.; Ramos, M.H.; Chavez-Tapia, N.C.; Uribe, M.; Méndez-Sánchez, N. High ghrelin and obestatin levels and low risk of developing fatty liver. Ann. Hepatol., 2010, 9, 52-57.

[84] Golestan Jahromi, M.; Nabavizadeh, F.; Vahedian, J.; Nahrevanian, H.; Dehpour, A.R.; Zare-Mehrjardi, A. Protective effect of ghrelin on acetaminophen-induced liver injury in rat. Peptides, 2010, 31, 2114-2117. 
[85] Cetin, E.; Kanbur, M.; Cetin, N.; Eraslan, G.; Atasever, A. Hepatoprotective effect of ghrelin on carbon tetrachloride-induced acute liver injury in rats. Regul. Pept., 2011, 171, 1-5.

[86] Arıc1, O.F.; Cetin, N. Protective role of ghrelin against carbon tetrachloride $\left(\mathrm{CCl}_{4}\right)$-induced coagulation disturbances in rats. Regul. Pept., 2011, 166, 139-142.

[87] Ceranowicz, P. Warzecha, Z; Dembinski, A. Sendur, R. Cieszkowski, J ; Ceranowicz, D.; Pawlik, W.W.; Kuwahara, A.; Kato, I.; Konturek, P.C. Treatment with ghrelin accelerates the healing of acetic acid-induced gastric and duodenal ulcers in rats. J. Physiol. Pharmacol., 2009, 60, 87-98.

[88] Warzecha, Z.; Dembinski, A.; Ceranowicz, P.; Cieszkowski, J.; Sendur, R.; Bilski, J. Ghrelin accelerates the healing of cysteamine-induced duodenal ulcers. Gut, 2009; 58(Suppl 2): A273.

[89] Warzecha, Z; Ceranowicz, P.; Dembinski, A; Cieszkowski, J; KusnierzCabala, B.; Tomaszewska, R.; Kuwahara, A.; Kato, I. Therapeutic effect of ghrelin in the course of cerulein-induced acute pancreatitis in rats. J. Physiol. Pharmacol., 2010, 61, 419-27.

[90] Ceranowicz, D.; Warzecha, Z.; Dembinski, A.; Ceranowicz, P.; Cieszkowski, J.; Kusnierz-Cabala, B.; Tomaszewska, R.; Kuwahara, A.; Kato, I. Role of hormonal axis, growth hormone - IGF-1, in the therapeutic effect of ghrelin in the course of cerulein-induced acute pancreatitis. J. Physiol. Pharmacol., 2010, 61, 599-606.

[91] Gonzalez-Rey, E.; Chorny, A.; Delgado, M. Therapeutic action of ghrelin in a mouse model of colitis. Gastroenterology, 2006, 130, 1707-1720.

[92] Konturek, P.C.; Brzozowski, T.; Engel, M.; Burnat, G.; Gaca, P.; Kwiecien, S.; Pajdo, R.; Konturek, S.J. Ghrelin ameliorates colonic inflammation. Role of nitric oxide and sensory nerves. J. Physiol. Pharmacol., 2009, 60, 41-47.

[93] De Smet, B.; Thijs, T.; Moechars, D.; Colsoul, B.; Polders, L.; Ver Donck, L.; Coulie, B.; Peeters, T.L.; Depoortere, I. Endogenous and exogenous ghrelin enhance the colonic and gastric manifestations of dextran sodium sulphate-induced colitis in mice. Neurogastroenterol. Motil., 2009, 21, 5970 .

[94] Adachi, S.; Takiguchi, S.; Okada, K.; Yamamoto, K.; Yamasaki, M.; Miyata, H.; Nakajima, K.; Fujiwara, Y.; Hosoda, H.; Kangawa, K.; Mori, M.; Doki, Y. Effects of ghrelin administration after total gastrectomy: a prospective, randomized, placebo-controlled phase II study. Gastroenterology, 2010, 138, $1312-1320$.

Received: August 15, 2011 Revised: November 08, $2011 \quad$ Accepted: November 10, 2011
[95] Yamamoto, K. Takiguchi, S ; Miyata, H ; Adachi, S.; Hiura, Y.; Yamasaki, M.; Nakajima, K.; Fujiwara, Y.; Mori, M.; Kangawa, K.; Doki, Y. Randomized phase II study of clinical effects of ghrelin after esophagectomy with gastric tube reconstruction. Surgery, 2010, 148, 31-38.

[96] Stengel, A.; Goebel-Stengel, M.; Wang, L.; Shaikh, A.; Lambrecht, N.W.; Rivier, J.E.; Tache, Y.F. Abdominal surgery inhibits circulating acyl ghrelin and ghrelin-O-acyltransferase levels in rats: role of the somatostatin receptor subtype 2. Am. J. Physiol. Gastrointest. Liver Physiol., 2011, 301, G239G248.

[97] Trudel, L.; Bouin, M.; Tomasetto, C.; Eberling, P.; St-Pierre, S.; Bannon, P. L'Heureux, M.C.; Poitras, P. Two new peptides to improve post-operative gastric ileus in dog. Peptides, 2003, 24, 531-534.

[98] Venkova, K.; Fraser, G.; Hoveyda, H.R.; Greenwood-Van Meerveld B. Prokinetic effects of a new ghrelin receptor agonist TZP-101 in a rat model of postoperative ileus. Dig. Dis. Sci., 2007, 52, 2241-2248.

[99] De Winter, B.Y.; De Man, J.G.; Seerden, T.C.; Depoortere, I.; Herman, A,G.; Peeters, T.L.; Pelckmans, P.A. Effect of ghrelin and growth hormonereleasing peptide 6 on septic ileus in mice. Neurogastroenterol. Motil., 2004 , $16,439-446$

[100] Akamizu, T.; Iwakura, H.; Ariyasu, H.; Hosoda, H.; Murayama, T.; Yokode, M.; Teramukai, S.; Seno, H.; Chiba, T.; Noma, S.; Nakai, Y.; Fukunaga, M.; Nakai, Y.; Kangawa, K.; F.D. Clinical Study Team. Repeated administration of ghrelin to patients with functional dyspepsia: its effects on food intake and appetite. Eur. J. Endocrinol., 2008, 158, 491-498.

[101] Ejskjaer, N.; Dimcevski, G.; Wo, J.; Hellström, P.M.; Gormsen, L.C.; Sarosiek, I.; Søfteland, E.; Nowak, T.; Pezzullo, J.C.; Shaughnessy, L.; Kosutic, G.; McCallum, R. Safety and efficacy of ghrelin agonist TZP-101 in relieving symptoms in patients with diabetic gastroparesis: a randomized, placebo-controlled study. Neurogastroenterol. Motil., 2010, 22(10), 1069e281.

[102] Popescu, I.; Fleshner, P.R.; Pezzullo, J.C.; Charlton, P.A.; Kosutic, G.; Senagore, A.J. The Ghrelin agonist TZP-101 for management of postoperative ileus after partial colectomy: a randomized, dose-ranging, placebo-controlled clinical trial. Dis. Colon Rectum, 2010, 53, 126-134. 